\title{
PATHOLOGICAL STUDIES ON THE LIVER OF AUTOPSY MATERIAL IN LEPROSY (Part 2)
}

\section{Seitaro OKADA}

(National Leprosarium, Tama Zenshoen)

The following results were obtained from the macro- and microscopical examinations on the liver of autopsy material of 20 leprous cases (lepromatous 19 and neural 1).

1) The degree of histological and bacteriological improvement of lepromata in the liver is proportionate to that of lepromata in the skin.

In the relapse after temporary improvement, the course of lepromata in the liver is in proportion to that of skin lesion, but the liver change is not always subordinate to the skin lesions. Sometimes, the local relapse of lesion takes place in the liver, which can be the sourse of aggravation of skin and general disease.

2) In some cases the progresses of development of change in the lobule differ from that in the interstitium.

3) There exist macroscopically yellowish and whitish lepromata. This difference of the color tone is originating in the quantity of lipid in lepra cells of the lepromata.

4) The distribution of hematogenously disseminated leprosy bacilli is not always equable, but various in each loubule or in part of the lobule itself.

5) Though many factors except leprosy can influence upon the liver cells, atrophy, necrosis and disappearance of liver cells may be attributed directly or indirectly to leprosy, for example the pressure of numerous lepromata in the lobule, or the local congestion due to stenosis or obliteration of the central veins caused by the leprous changes.

6) The fatty degeneration caused by leprosy takes the type of peripheral fatty degeneration.

7) Leprosy shows a stronger tendency than tuberculosis to affect the central veins.

8) The proliferation of the interstitium is generally in proportion to the degree of changes in liver, and is also influenced by the ratio occupied by the improving lepromata. And there seems to exisit the disparity in the intensity of connective tissue reaction between the individuals.

9) The elastic fiber is weaker in resistense than the reticular and collagenic fibers, and easily broken and disappear and difficult to regenerate. Besides such remarkable breaking and disppearence, new growth of the elastic fibers, though in a slight degree, can be observed in some cases.

10) The vessels, regarding the tunica intima of the arteries, in the interstitium undergo leprous changes often, and sometimes the veins are invaded.

11) The individual differences of the intensity of connective tissue reaction participate in the thickning of the liver capsule as well as the proliferation of interstitium.

\section{癩患者剖検例の肝臓の病理学的研究（第 2 報）}

\author{
多磨全生園（園長 林芳信） \\ 岡 田 誠 太 郎
}




\section{緒言}

本篇は20例の癩患者剖検例の肝の病理組織学的な研究 の報告でもる。癩患者殊に癩腫瀨患者の肝臓の病理組織 に就ては, 古くから Hansen, Cornil, Babes, Jeanselme, de Beurmann, Gougerot, Schäffer ${ }^{(6)}$, Nєisser ${ }^{(7)}$, Doutre lepont ${ }^{(8)}$, Wolters, Musehold ${ }^{(9)}$ 等を始め多数の諸家が報 告して居り, 我国に於て子菅井(10)，竹崎(11)，光田(12), 小林(1)，宗内(2) 等の報告があるが，本篭に於ては既に 婁々報告されている綜括的な或は最大公約数的な典型の 記载は簡単にとどめ，攋腫溜患者の肝に現れる各種の病 单像，吸収された病巣像，或は陳旧性の吸収された病采 内の菌の特異な所見等を始め，瀨性病㮍，結綂織，中心 静脈，胆管等に就て特異な所見を報告し，又個体に上る 瀨性病栄の差異或は結䋨織反忘の差異，皮疹と肝の瀨腫 との関係, 肝細胞の変性の考祭等を始め単なる肝の病変
の記載以外の種々の考察に重きを怙いて記述した。

\section{実験材料及方法}

昭和24年11月より昭和25年10月に至る閒に全生園に於

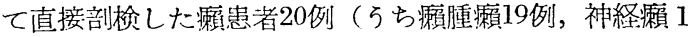
例）の肝陚に就てその肉腿的及顕微鏡的所見を調べた。 鏡検材料はオルト氏液固定後一部はパラフイン包埋とな しへマトキシリン・エオジン，ワンギーソン，ワイゲル ト，ビルショウスキー・岡，マロリーの各染色を行い， 一部は凍結切片となしへマトキシリン・エオジン，ズダ ンIII及チール・へマトキシリン染色を行つた。

\section{実験結果及考察}

各例に就ての詳細な記述は省略し，主な項目に関する 主な所見を緾めて表 1 とした。

表 1

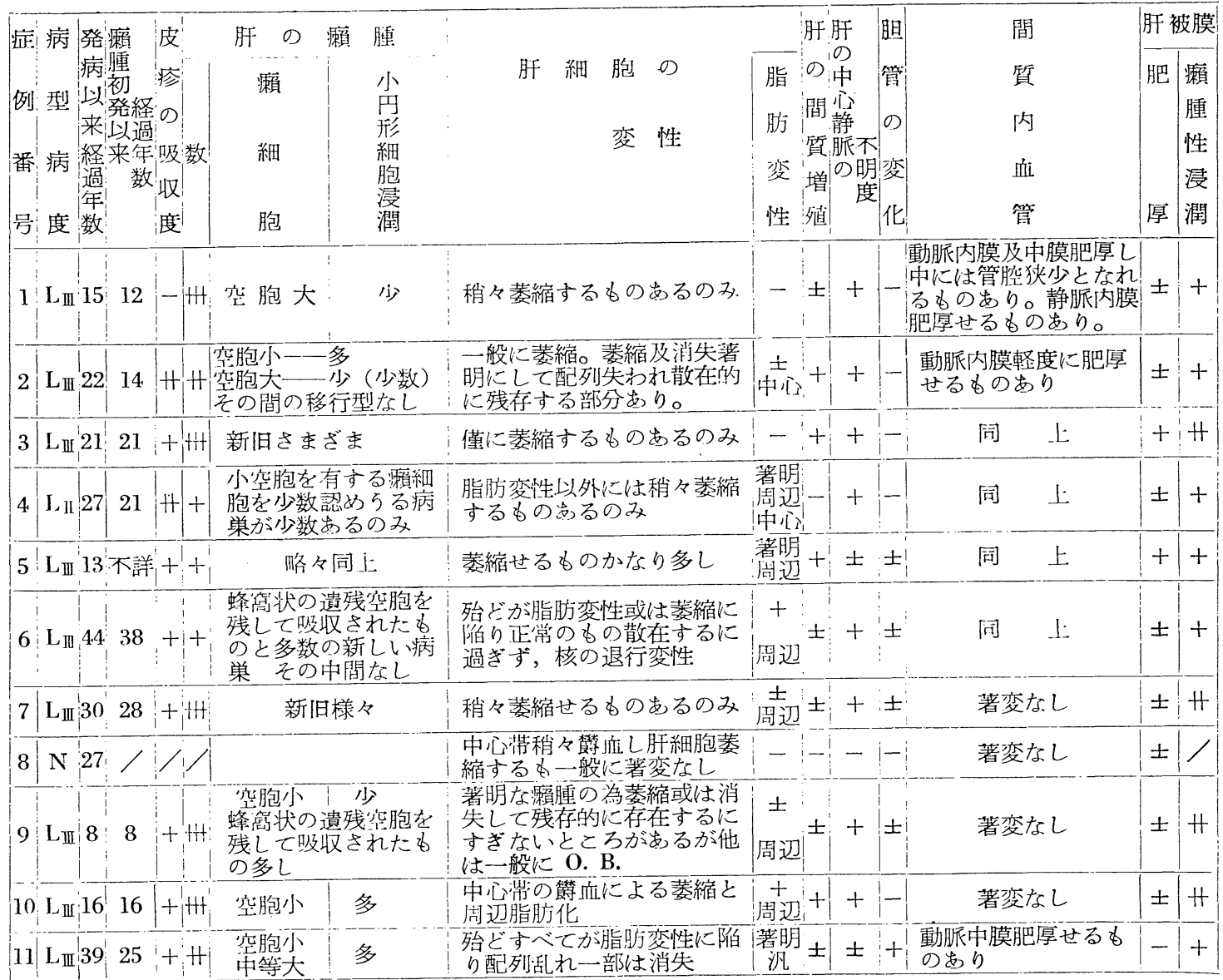




\begin{tabular}{|c|c|c|c|c|c|c|c|c|c|c|c|c|c|c|}
\hline 12 & $\mathrm{~L}_{\mathrm{II}}$ & 13 & 13 & $+H+t$ & $\begin{array}{l}\text { 空胞 } \\
\text { 中等大 }\end{array}$ & 多 & $\begin{array}{l}\text { 萎縮, 消失, 疎開, 配列乱 } \\
\text { る }\end{array}$ & $\begin{array}{c}+ \\
\text { 周辺 } \\
\end{array}$ & + & \pm & \pm & $\begin{array}{l}\text { 動脈内膜軽度に肥厚 } \\
\text { せるすのむるも一般 } \\
\text { に変化少なし }\end{array}$ & - & + \\
\hline 13 & $\mathrm{~L}_{\mathbb{I I}}$ & & 14 & $+\mathrm{H}+$ & $\begin{array}{l}\text { 空胞小 } \\
\text { 中等大 }\end{array}$ & 多 & 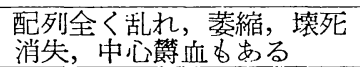 & \begin{tabular}{|c|} 
\pm \\
$\mid$ 周辺
\end{tabular} & + & \pm & +1 & $\begin{array}{l}\text { 動脈内膜肥厚せるも } \\
\text { の多し }\end{array}$ & + & $H$ \\
\hline 14 & $\mathrm{LIII}_{\mathrm{II}}$ & 18 & 17 & $|+| H+$ & 空胞小二 & 一多殆どなし & 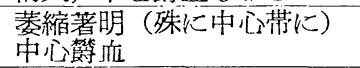 & $\begin{array}{c} \pm \\
\\
\text { I周辺 }\end{array}$ & \pm & + & + & $\begin{array}{l}\text { 動脈内膜肥厚せるも } \\
\text { のま り }\end{array}$ & \pm & + \\
\hline 15 & $\mathbf{L}_{\mathrm{III}}$ & 21 & 6 & $+H H$ & 空胞小 & 多 & 空胞変性 & - & \pm & \pm & \pm & 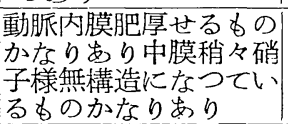 & \pm & H \\
\hline 16 & $L_{\text {III }}$ & & 17 & $++H+$ & $\begin{array}{r}\text { 中空胞小 } \\
\text { 中等大 }\end{array}$ & 多 & 中心䬳血，萎縮，消失 & $\mid \begin{array}{c} \pm \\
\text { 周辺 }\end{array}$ & - & \pm & +1 & $\begin{array}{l}\text { 動脈内膜肥厚せる } \\
\text { のおり }\end{array}$ & - & + \\
\hline 17 & $\mathrm{~L}_{\text {III }}$ & 28 & 21 & $\mathrm{HH}$ & 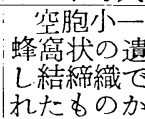 & $\begin{array}{l}\text { 少或稍々多 } \\
\text { 残空胞を残 } \\
\text { 打きかえら } \\
\text { なりあり }\end{array}$ & 著変なし & \pm & + & + & - & $\begin{array}{l}\text { 動脈内膜倯々肥厚せ } \\
\text { るものまるも一般に } \\
\text { 変化少なし }\end{array}$ & - & + \\
\hline 18 & $\mathrm{~L}_{\text {III }} \mid$ & 14 & 13 & $+\mathrm{Ht}$ & 新旧 & 様々 & $\begin{array}{l}\text { 周辺带に萎縮，消失せるも } \\
\text { のあり }\end{array}$ & $\begin{array}{c}+ \\
\mid \text { 周辺 }\end{array}$ & + & \pm & -1 & $\begin{array}{l}\text { 動脈内膜肥厚せる多 } \\
\text { のあり }\end{array}$ & \pm & + \\
\hline 19 & $\mathrm{~L}_{\mathrm{II}}$ & 40 & 26 & $\mathrm{H}+$ & $\begin{array}{l}\text { 蜂窝状の遗 } \\
\text { して吸収さ } \\
\text { は大部分結 } \\
\text { かえられた } \\
\text { 空胞を有す } \\
\text { 少数有する }\end{array}$ & 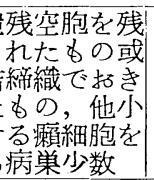 & $\begin{array}{l}\text { 全く大小不同, 各個ばらば } \\
\text { らの如くに存在, 配列全く } \\
\text { 先われ, 空胞変性, 核の退 } \\
\text { 行変性等 }\end{array}$ & - & + & + & \pm & $\begin{array}{l}\text { 動脈内膜或は中膜も } \\
\text { 肥厚せるものむり }\end{array}$ & \pm & - \\
\hline 20 & $\mathrm{~L}_{\mathrm{II}}$ & & & $1+H+$ & 新旧 & 様々 & $\begin{array}{l}\text { 萎縮, 一部の消失, 肝細胞 } \\
\text { 索断裂, 固有の配列乱る }\end{array}$ & 声 & \pm & + & \pm & $\begin{array}{l}\text { 動脈内膜の稍々肥厚 } \\
\text { せるものあり }\end{array}$ & - & + \\
\hline
\end{tabular}

(1) 癩腫癩患者に就てその病度と朋の癩腫性病 変の程度との関係に就て

$L_{\text {III }} 17$ 例の 5ち肝の癩腫性病変の程度 ( $\left.t+t\right)$ のもの 13 例，(H) 2 例，（+） 2 例， $L_{I I} 2$ 例はいづれも $(+) 。$ この点は先の肉眼的所見の統計と同様の傾向を示して居 り，先の統計に於て肉眼的に見得る瀨腫の程度と病度と の関係をみたが，顕微鏡的にみて肉眼的には見得ない微 小癩腫を含めても肝の癩腫性病変が主に皮圈の癩腫の程 度から決定する病度と或程度比例するととを示してい る。しかしながら個々の例に就てみてゆくと，皮度に於 ける瀨腫の初発以来の経過年数, 死亡時の皮疹の㹡がり の程度，皮疹の吸収の状態等が略々同様でめる例の間に 於て, 肝の瀨腫性病单の数, その個々の病单の進展の状 態等が異なる場合がある。これは皮㲊の病巣に於ける而 管の侵され方の差による菌の血行性撒布の差等の細かい 皮膚病巣の差心もよるであろらが，既報(う)の如く鼠癩に 於て皮膚の鼠瀨腫が略々同様の程度で肝の病変の異る 2 群に於て門脈より同一菌量を注射してその後に起る病変 を観察すると，大体に於てではあるが 2 群間に於ける新 生病巣の程度の差が，注射前の病変の程度の差と比例す るといらことからみて, 或程度肝の局所的な, 広い意味 での抵抗力の差といらものがあると考えられる。

（2）皮疹の吸収度と肝の癩腫数

瀨腫瀨患者のちち $\mathrm{L}_{\text {II }}$ の 2 例を除き $\mathrm{L}_{\mathbb{I I I}}$ ばかりの例 17
例に就て皮疹の昅収度と肝の癩腫数の関係を表 2 にして タた。

表 $\quad 2$

\begin{tabular}{|c|c|c|c|}
\hline $\begin{array}{c}\text { 皮疹の吸収度 } \\
\text { 肝の倠腫数 }\end{array}$ & - & + & $H$ \\
\hline+ & 0 & 2 & 2 \\
\hline$H$ & 0 & 1 & 1 \\
\hline$H$ & 1 & 11 & 1 \\
\hline
\end{tabular}

之よりみると大体に於て皮疹の吸収度が高いもの程肝 の癩腫数は少ない。乙れは皮疹の吸収と共に肝の癩性病 変もそれに伴つて軽快過程が始まり,一般に個々の病巣 が小さい肝に於ては, 軽快過程に於て殊に小ない空胞を 少数有する泍細胞が少数ある如き病巣は, 癩細胞が次第 に新しい単球系細胞によつて括きかえられ，次第に病巣 全体が非特異的な病巣像を示すに至るものがでてきて 「癩腫性」の病巣数は少くなり, 更に一般的な軽快過程 の為に新病巣の発生も少くなる為と考えられる。そして かかる瀨腫の減少消失は先に報告(5)した二次的神経瀨の 肝の所見に於て，空胞の遗残はみられるがその数はそれ ほど多くはないといらととを併せ考えると，いくら軽快 しても遣残する如き大なる空胞を有する癩細胞が多数め るといらところまで顀が進展せず，空胞はむつても未だ 余り大とならざる瀨細胞よりなり軽快過程と共に空胞の 遗残を残さず新しい単球系細胞によつて括きかえられ， 
非特異的な像に移りらる病巣位にしか進展していない病 单があだ比率的に多いらちに治療による軽快過程が開始 されるか否かといらととにも関係するのではないかと考 えられる。

(3) 肝の癩腫の肉眼的所見及組織像飞就て

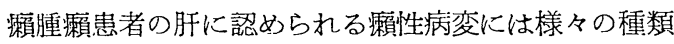
がある。例えば少数の菌を喰した星占状細胞或は単球と 小円形細胞よりなり未污癩腫性」としての特異的な像 を示さない懶性の小病巣，小なる空胞を有する少数の癩 細胞と菌を喰してはいるが未げ空胞形成のない単球系細 胞と小円形細胞よりなる病巣，小なる空胞を有する痰細 胞群と比較的多数或は比較的少数の小円形細胞よりなる 病巣，大なる空胞を有する瀬細胞と少数の小円形細胞よ り成る病巣，中央は大なる空胞を有する癩細胞と少数の 小円形細胞よりなり，その周囲を小なる空胞を有する襀

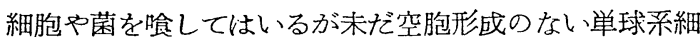
胞と比較的多数の小円形細胞がとりまいている病巣, 瀬 細胞の核も不明となり殆ど蜂窩状に空胞のみ遗残するも の等があり，蜂窩状の構造のみを残すものに於ても個々 の空胞が極めて大なる場合とそれ㤬ど大きくない場合と がある。又蜂窩状の構造が増殖せる結締織によつて被包 されたるが如きものや，結締織によつていくつかの空胞 群に分割されている様なものもある。瀬細胞の空胞は往 々間質に於けるものに大なるものがあり，皮筒に於ては 余り見られない様な大なる空胞の集りをみるととがあ る。

一般に小葉内に於ては病巣が小なるまをに空胞を形成 せる瀨細胞の小集団となつて局限する傾向がある様で， 周辺に小円形細胞を比較的に多数に含む浸潤層をつけな がらひろがつてゆくもののある間質内と稍々趣を異にす る傾向が往々見られる。勿論小葉内に於ても一見空胞比 較的大なるる小さく局限した様な彩腫が，肝細胞の網の 目をみたす様に集つていて，それらの一見小病巣群の集 りの如きものの周辺の方には小円形細胞と菌を喰した単 球或は新しい㸊細胞からなる小病巣が肝細胞索の網の目 の中に認められる様なところがあり，かかる所ではてれ らの病巣群はもし立体的にみてみたならば樹枝状につな がつていて，中央の方は比較的空胞形成著明な制細胞群 で，その周辺部には未熟な瀨細胞と比較的多数の小円形 細胞がとりまいている形になつているものと思われる。 このように小葉内の病巣でも間質内の病巣と余り本質的 には差がなく，ただ肝細胞索間を縫つて発展したために 切片で断面をみると上記の様な小病巣の集りの様にみえ
るといら場合もめる。との様な場合も勿論めり大体の傾 向の差としてではむるがやはり小葉内と間質内の病巣に 就てその比較的初期の進展が少し異る様に思われる。か かる小葉内と間質内の病栄の進展経過の差は, 既報 ${ }^{(5)} の$ 如く鼠瀬に於てもみられたものであるが，人澒に於ては 鼠瀬に比べその差ははつきりしていないで，例えば鼠癩 の小葉内に於てはきれいな小円形に局限した小鼠影腫の 如き特異な病巣の形成がみられるが，人瀨に於てはそれ ほど特異な像はみられない。その後の空胞形成に就ては 既述の如く間質内に於けるものに往々大なる空胞形成が みられ，皮膚に於ては余り見られない様な大なる空胞の 集りをみるととができる。

これらの瀨腫性病変のらち病巣の抎がり及び細胞の密 度によつて肉眼的に見得るものや見得ないものがある訳 であり，見得るものは所謂微細塵点状の病栄といら形を とる。往々肝を切割しないで既に被膜を透してて被膜直下 の瀬腫を多数に見得ることがある。肉眼的に見た場合， 典型的な黄色のものと，寧ろ白色に見えるものとある。 症例により殆どが黄色の瀬腫として認められるもの或は 殆どが带黄白色のものとして認められるすのがあり，か かる例の肉眼的に見得る霜腫の組織像の傾向を調べてみ ると，带黄白色乃至は寧万白色の頼腫は肉芽腫細胞群の なかの空胞が小でその数も少ないが，黄色の色調の強い 瀨腫の方は大なる空胞を有する指罢状の細胞，或は 1 藾 細胞内に個々の空胞はとれほど大きくないが多数の空胞 があつて細胞質は恰も空胞の隔壁の如き形に王迫されて いる細胞が，その主要構成因子となつて居り，いづれに せよ衤腫に於ける空胞の占める割合が大である傾向がめ り，結局肉眼的に夕た場合のかかる色の差は，単位体積 の瀬腫内に含まれるリポイドの量の差によるものと考古 られる。そして又鼠瀨に於て内臓の鼠瀨腫が人瀨に於け るもの活ど黄色の色調の強いものがないのも, 鼠㹕細胞 は瀬細胞に比べ大なるリポイド球の沈着を来さないで小 なるリポイド顆粒の沈着にとどまるととによるすのであ ろら。な打肉眼的に見大場合少数例飞就てではめるが肝 の各葉及び部位による䨋腫の数に差がむるものがあつ た。No.3,5に於て Lobus dexter よりも Lobus sinister の方が稍々衵腫が多く, 又 No. 3,9 に於て Lobus caudatus 或は Lobus quadratus に於ては他葉よりも 稍々制腫が少かつた。部位に就ては肉眼的に䫐腫の分布 状態をみても又組織学的に数及組織像をみても，例えば 肝縁乃至それに近い部分, 肝縁から離れた葉の中央の辺 の部分，又肝縁から離孔ても割面に於て横隔膜面に近い 方と内臟面に近い方などで, 瀨腫数及積腫の組織像の傾 
向が稍々異る場合があり，決して血行性に撒布された菌 の肝に於ける附着がどのたびに於てる均等だとは限らな いものでめると考学られる。

瀬細胞の空胞小にして小円形細胞の比較的多くしかも 殊に菌が桿状のものが多い、顧腫は比較的新しい、瀨理之考 えられ，空胞大にして小円形細胞も比較的少く菌型が顆 粒状等に崩れているものが比較的に多いるのは比較的古 い獺腫であり，瀨細胞の核も多くが不明となり空胞が遣 残して蜂窩状の構造のみを残し菌は認められないか或は 顆粒状等の変型菌が僅汇認められるのみといら瀨腫は陳 旧性のしかも吸収された瀨腫と考えられる。単球系細胞 と小円形細胞よりなる病巣の場合, 桿状の菌が単球系 細胞内に認められるものは新しい「前衤腫性」の病巣と 考えられるが，菌が認められないものは前櫴腫性の意味 の場合も岕るし，未成熟な典腫のうちに治療によつて軽 快機転が始まつて小なる空胞を少数有する數細胞は新し い単球系細胞儿よつて拓きかえられて非特異的な病巣に なつたといら意味のものもあると考えられる。従つてか かる像を示すものは，個々の病巣比就てはその性質を知 るととはできないる攋腫瀨患者を通じてみると肝歲にこ れら各種の瀨腫がみられるが，個々の症例に就てみると 大体の傾向がめり, 比較的新しい攋腫の多いもの, 比較 的古い癩腫の多いもの, 或は新旧様々の段階のものが見 られるもの, 比較的新しいものと古いわのとがありその 間の中間型の余りないもの, 或は蜂堂状の構造を残して 吸収され菌は殆ど認められないか或は顆粒状等の変型菌 が僅数認められるのみの陳旧性の吸収された瀨腫と一方 に於て新しい瀬腫が混在するもの等がある。これらに就 ては，例えば新旧様々の段階のものがみられる例はずつ と以前から現在に至る末で余り病勢の落ち着いた時期が なく, 菌の血行性の撒布が屢々繰り返されている例と考 えられ，事実皮疮等に就ての過去及現在の病勢がそらい 5状態である例があり, 又比較的古い瀨腫が多く新しい 灀腫の少ないものは，以前は病勢がかなり強かつたがそ の後比較的落着いてますり菌の血行性撒布が顕著に起ら ないものでめり, Х一方に於ては蜂窩状の構造を残して 吸収され菌も殆ど認められないか或は顆粒状の変型菌が 僅に認められるのみの陳旧性の吸収された攋腫があり， 一方には新しい攋腫が混在するといら例は以前は病勢が かなり強かつたが，その後比較的落着いて静止状態が続 き, 何年か後に再び増恶して菌の血行性撒布により新病 巣の形成が起つた例と考えられる。事実 No. 6 は顔面に 瀨腫が初発したのは38年前でありその後軽快著明な状熊 となつていたが，攋腫初発以来 27 年にして再び増悪し顔
面その他に瀬腫が新生した例であるが，本例に於ては上 述の如く瀨細胞の核も殆どが不明となり遗残空胞の集り でもる蜂简状の構造を残して吸収された病巣と，小なる 空胞を有する少数の䎦細胞と淋巴球，単球等よりなる少 数の比較的新しい小病巣とが認められ，との両者の中間 に相当するものは余り認められない。

䗋笠状の遗残空胞と云つても例によつては個々の空胞 が極めて大なる場合と，個々の笁胞忙とら大きくなく1 個の冨細胞内にそら大きくない空胞が密集し，細胞質は 単に空胞の間の隔壁の如き形で存在するといら瀬細胞が めるがその椂な空胞の遗残の如き形の場合とがある。こ れは軽快機転が始まつた時の空胞の成熟状態の差による

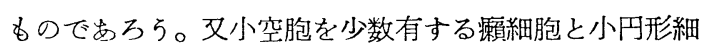
胞，単球よりなる病巣で菌が桿状のものである場合は， 比較的新しくしかも未轻快機転の始をらない病巣でむ るが，かかる組織像で菌が顆粒状等の変型菌が多いのは 未だ新小病巣の時期に軽快し始めた時期のものと考えて よいと思ら。そしてかかるものがもつと著明に軽快した 時には，小空胞を少数有する瀨細胞は新しい単球によつ て括きかえられて非特異的な像に变つてゆくのである が，とにかく個々の空胞の大さは病巣によつて違らにせ よ蜂窝状の遣残空胞が認められ，他には小空胞を有する 少数の瀨細胞を含むのみの小病巣でしかもその中の菌型 は变型菌が多いといら病巣が少数あるのみといら例があ るがかかる例は皮疹の吸収の比較的著明な例である。し かしこの逆は必ずしも成立しない。皮疹の吸収が比較的 著明な例で岕つて蜂总状の遣残空胞はなく，顆粒状等の 变型菌が少数認められる瀨細胞とそれに小円形細胞の比 較的多い病巣及び非特異的な病巣が認められるのみとい ら形をとるものも岁。とれは結局吸収機転が始まつた 時の瀨腫の進展状態の差によるものと思われる。

しかしながらいづれにせよ皮疮の吸収の状態と肝の癩 腫の吸収の状態とは大体に於て並行するものであるとい、 らととは云える。しかし No. 20 に於てその 1 陳旧性の 病单内でその大部分は菌も顆粒状等の変型菌が少数認め られる位でめるに拘らず，或一部分に於て典型的な桿状 のしか子抗酸性の強い菌が集簇して小塊を形成している のが認められた。これは陳旧性のしかも或程度吸収され かかつた病巣内の菌が何らかの機転で再び旺盛な分裂増 殖を開始し桿状の抗酸性の強い菌の集塊をつくつたもの と思われ，かかる菌の増殖が更に進展して次第に周囲に 菌が抎がり近くの血管より血流中に入り癩の増恶を来す のではないかと思われる。又 No. 9 に於ては陳旧性のか なり吸収された病巣の周囲をめぐつて新しい、蟦細胞を含 
んで浸潤が起つてそとに桿状の菌が認められる病巣があ つた。とれらの像から考えて，肝の如き内臟が全身的な 増恵の源となる場合もあると考えられる。徉つて肝の癩 腫の状態は前述の如く皮疹の状熊と正行するるのである

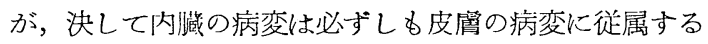
ものではなく，時には内缄が Schub の源となる場合も あるものと考它られ，とのととは経過と予後の判定に於 て念頭に入れて扔かなければならないととで岁ると思 ら。

\section{(4) 菌所見に就て}

菌を喰した単球或は小空胞を少数形成せるのみの霣細 胞内の菌は，未だ全般的な軽快機転が作用していないも のでは, 桿状の抗酸性の強い菌であるが, 顆細胞内の空 胞大となり稍々古い病巣内の菌は次第に顆粒状, 断裂状 等の変型菌が多くなつてくる。肝では上述の様に皮有で は余り見られない様な大きな空胞を形成した瀨腫が霆々 あり，従つて全般的な軽快機転が始李らないらちに既に 皮膚に比へ顆粒状等の変型菌がより屡々認められる。な 打陳旧性の病巣では往々非抗酸性の菌が認められる。㖽 細胞内の空胞小にして少数である新しい病巣内の菌は上 述の如く桿状の抗酸性の強い菌であるが，かかる病巣も 軽快機転が作用し始めると菌は次第に断裂状等に変型し てくる。中央は大なる空胞を有する制細胞より成り，周 辺は小なる空胞を有する瀬細胞と小円形細胞, 単球より なる病巣では, 中央は変型菌が多く, 周辺は桿状の菌が 多い。同じ大さの病巣でもとの様なるのと, 又中央部の 瀨細胞の空胞も未代余り大ならず，菌型もとら崩れて居 らず，小空胞を有する顧賥胞及菌を喰した或は喰さざる 単球と小円形細胞よりなる周辺部との差が余り著しくな いものとがあるが，かかる二種類の病巣の細胞及菌型に 関する差は，その病巣の進展速度の差によるものと考え てよいであろら。蜂窩状の遣残空胞を残して吸収された 陳旧性の病巣内では既述の如く菌が殆ど認められない か, 又は顆粒状の菌が少数認められるに過ぎない。なお 従来往々間質内では顆粒状等の変型菌が屡々認められる が，星出状細胞内の菌は桿状でもるといらととが言われ たが，乙れは結局菌の存在する病巣乃全細胞の新旧の差 に過さない。星芒状緗胞が菌を喰しているといつている 場合は, 菌が或一細胞内に捉えられたばかりのいはば初 期の病巣像を見ているわけであり, その星芒状細胞内で 菌が增殖し細胞内に空胞が生し，周辺にも瀨細胞が形成 されて小葉内の小顧腫を形成するに至れば，始の星芒状 細胞内の菌型も次第に崩れてゆく。又一方間質に於て
も，菌を喰してはいるが未だ空胞を形成していないい つかの細胞と小円形細胞等よりなる新しい病巣では, 菌 は桿状のものでする。従つて星芒状細胞内の菌のみが他 と異つた態度をとるといらわけではなく，単に星芒状細 胞が菌を喰しているのみで周辺に他の細胞浸潤も未だな いか，或はめつても少数の小円形細胞のみといら様な新 しい初期の病栄の典型を星芒状細胞の部位で展々見得る といらに過ざない。その他二，三の特異な菌所見に就て は夫々他の項目に述べてある。

（5）肝細胞飞就て

肝細胞の菱縮, 消失, 空胞变性, 脂肪変性, 核の退行 変性等種々の变性が認められることがあり，No. 19 の如 く肝細胞は全く大小不同にして恰も各個ばらばらの如く に解離して存在し，肝細胞特有の配列は全く失われてい る場合がむる。かかる肝細胞の萎縮, 消失, 肝細胞索の 解離，配列の乱れ等が，小葉内に多数に生じだ㸊腫の圧 迫の為に起つたと考光られる場合があり，例えばNo.9 に於けるが如く小葉中心帯或は周辺帯に於て多数の頙腫 がつながつて肝細胞索間を埋め，珠に小葉中心带に於て 著明なところでは肝細胞は萎縮或は消失し，それら残存 せる萎縮した肝細胞の間に頛細胞の浸潤が綸状に連り， 恰も榔血肝の中心帯の像に於ける㹡張せる毛細血管の部 分を攋細胞と置換した様な形状を呈している様な場合が むる。かかる例に於ける肝細胞の萎縮, 消失は明らかに 瀬腫の圧迫が，少くともその最大原因となつていると考 えられる。又No. 2 に於ける如く小葉の中心にして中心 静脈のあるべき部位に癩腫が認められ，中心静脈の管腔 は消失しその周辺の肝毛細血管に辳血が認められ，その 小葉中心带の肝細胞が萎縮しているが如き例があり, 又 中心静脈周辺に瀨腫が殆ど環状に存在する場合があり, とにかく一般に獺腫瀨患者の肝では中心静脈の不明な場 合が多いが，かかる中心静脈の癩性病变或はその周囲の 櫴腫の圧迫による中心静脈の狭窄又は閉鎖等の為に生ず る局所的な榔血による肝細胞の萎縮といら場合もあると 考えられる。この様に肝細胞の萎縮, 消失等に就ては直 接，間接に制に原因するものがあるが，乙かし例えば No. 19 に於て，乙の例は $\mathrm{L}_{\mathrm{II}}$ で皮疹の吸収度も比較的高 く, 肝の癩腫も比較的少数にしてしかも極めて陳旧性に して蜂窩状の遗残空胞を残しているもの或は大部分結䋨 織で打きかえられたものが散在し，その外には小空胞を 有する小病巣が少数認められるのみに過ぎず，又中心静 脈も比較的明らかなものがかなりあるにも拘らず，肝細 胞の萎縮，消失著明にして肝細胞索断裂し固有の配列を 
失つているが如き例があり，又統計的にも必ずにも箱の 病型病度, 吸収度, 肝の癩生病変の状態等と肝細胞の変性 は並行しないが，乙れは非常に多くの团子の影響を受け 易い肝細胞に就てはその奖性が必ずしも癩の病型病度, 吸収度, 肝の癩性病変の状態等と並行しない場合がある

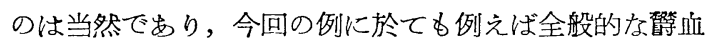
肝による小葉中心带の肝細胞の退行変性がみららる例が いくつかあり,神経瀨の例に於てもそれが見られている。 肝の脂肪変性に就ては第 1 報に既に述べたが今回の例で も瀬腫瀨患者に尿々みられ，その場合周辺脂肪化でむる 場合の方が多く, 時には肉堂䢰肝を呈するものがある。要 するに肝細胞儿就ては瀨以外の因子による影響と, 直接 或は間接に癩に起因する影響とを併せ考えなければなら ないが，上述の如く肝細胞の萎縮，壊死，消失及び脂肪 変性に関しては, 直接或は間接に瀨に起因すると考えら れるものがあり，No.9 の如く肝の瀨腫が著明な場合に はその直接の影響のみでも肝の機能に大なる影響がめる と考えられる。間接の影響としては上記の中心静脈の狭 窄或は閉鎖による局部的な箇血による肝細胞の萎縮の他 に，全身的な瀬による異常な代謝による humoral の肝 全般に影響を及ぼす因子のととも考えなければならない と思われる。

\section{（6）中心静脈飞就て}

癩腫瀨患者の肝の中心静脈は不明㿟であるものが虽々 あるととは既に述べた通りである。神経頖に於てはかか るととは見られない。な打今回のらち結核を合併し肝に 結核性病巣の認められたものが 6 例めるが, それらの例 に就てみると中心静脈に接して結核性病变が認められる ことが少ない。殊に神経瀨例でまり淟腫性病変のない No. 8 に就てみるに中心静脈に接して発生したととが明 らかでめる結核性病巣は余り認められず，彷つて中心静 脈は多くが明瞭である。又 No. 5 は LIII でむるが肝の瀨 腫は少数である例であるが肝に結核が合併しているにも 拘らず，との例は中心静脈の明膫なものがかなりむる。 これらのととから考えると結核と癩に於て中心静脈の侵 し方にいくらか羑があるのではないかと思われる。ての ことは実験的に結核に罹患せしめたモルモットの肝臓 （第23回日本瀨学会に報告した「プロミンが骨結核に及 ぼす影響の実験的研究」に使用せるモルモットの肝蔵に 就て調べた）に就ても略々同様の傾向が認められた。又 一方実験的鼠瀨に就てみるに，乙の場合は人瀨と同様に 中心静脈が屢々侵されるととは既に報告した(5)。

（7）肝の結締織に就て

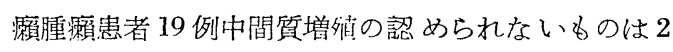
例，軽度に認められたもの8 例, 稍々著明なもの 9 例で ある。病型と間蜇増殖との関係に就ては今回の例のらち 神経澒が 1 例で他は全部瀨腫瀨で山る為, 今回の例のみ からは結論は下せないが，今回の 1 例及先に報告(5)した ビオプシーを行える神経瀬 3 例のいー゙れにも間䚀増列を 認めなかつたとと，ビオプシーを行える斑紋獺 5 例 ${ }^{(5)} に$ 於てはそれらはいづれも明な合朔症のない例であるが， 間質増殖の認められる例もまつたが全般的には瀨腫瀨に 比べ頻度及程度は少ないといらとと，第 1 報に述べた様 に瀨腫瀨患者に於ては，瀨以外で肝に間質増殖を来す如 き疾忠を合併しているものを極力除いたまとの例に於 て，肉眼的に明な䦭質增殖を来しているものが多数むつ たといらとと，とれらのととから肝の間質増殖は病型に より差異があるととが云える。而して間質増殖の傾向が $\mathrm{L}>\mathrm{M}>\mathrm{N}$ でまるととは, 肝の櫴性病变の程度が $\mathrm{L}>\mathrm{M}$ $>\mathrm{N}$ であるととと比例する。今回の瀨腫䙡例に就てみて も肝の攋腫の程度と間質増殖との間に或程度の関係がみ られる。しかし個々の例に就てみると必ずしもきれいな 比例はみられない。とれは勿論第 1 報に述べた様に瀨以 外で肝の間質増殖を来す如さ聅患の合併の影響も㐌るで あろらが，その様な疾患を合併せざる例の間に於ても肝 の泍腫数は略々同様でむりながら或程度の差異が認めら れる場合がある。とれは細かくみてゆくと，それら個々 の例の肝にむる瀨腫のうち新しい瀨腫と陳旧性の攋腫の 比率の差異にもよると考えられ，又例によつては同じ様 な状態の瀨腫のある部位でも，例えばNo. 2, No.6の如 く結締織性の反心忍䘡的強く起つている例と, 弱くし か起つていない例とせり，てれには組織反心の様式に個 体的な差があるものと考えられ，例えば一般に陳旧性の 瀨腫の部分では新しい哃腫に比し比較的に結䋨織が多い ものであるが，個々の例に就てみると蜂窩状の構造の瀨 腫が恰も増殖せる結䋨織によつて被包されたるが如き観 を呈しているものや，結締織によつて小群の蜂简状構造 に分割されている様なもの或は中心静脈周辺にかなりの 結綝織塊が女り，その中に空胞の遺残が少しまり，正常 状態では結締織の余りない部分でもるだけに，癩性病変 が陳旧性で吸収期に入り結綿織増殖と共に浸潤の大部分 が結䋨織によつて扣きかえられ空胞のみ残つたと思われ る様なあのなどがあり，てれらは結締織性の反応が比較 的著明なものでめるが，之に反し例之ば蜂䆚状の遺残空 胞が余り結䋨織の增殖を伴わずに残存するものなどがあ る。以上述べた様な様々の因子が組み合されて個々の例 の間質の状態が決定されるので，個々の例に就てみた場 
合一見肝の瀨性病変の程度と間質増殖との間に必ずし \& 一定の比例がみられない場合があるととになるものと考 えられる。

結綵織線維のらち弹力線維と癩性病変との関係に就て は，皮㜿の所見よりして瀨腫の場合瀨腫の成熟につれ断 裂或は消失してゆくものであるととが一般に云われて居 り，肝の癩腫性病巣に於ても同様なととがみられるが， 弾力線維と癩腫性病单との関係が, 弾力線維の断裂, 消 失といら面のみでなく, 弾力線維の新生といら面はない ですろらかといらととを，正常状態に於ては弾力線維の 存在しない小㷊内肝細胞索間の瀨腫部位に於て調べてみ た。乙の点は正常状態に於て弾力線維の多い皮有に於て は軽度の新生では，はつきりした判定が下せないのと異 り，小葉内肝細胞索間では軽度の新生でもはつきりと判 定しらるわけでする。てれによると小葉内肝細胞索間の 癩腫の殆どに於て弾力線維は認められなかつたが, No. 7 に於てかかる部位の瀨腫にしてその内に僅かの弾力線 維を認めたものがむつた。又 No.10 に於て恰もグッッ ソン氏鞘よりそれに接した小葉内肝細胞索間に無数にむ る瀨腫に向つて廖原線維及び弾力線維がのびているかの 如くに線維の増殖がみられた部位が出つた。又中心静脈 周辺の陳旧性病巣にして弾力線維の增殖を思わせるもの があつた。とれらのととから瀨腫性病栄に於て弾力線維 は断裂，消失の過程をとるのみでなく，新生或は再生と いら面も市りらるととを知つた。ただそれがあつても非 常に弱い為にもともと弾力線維の多い皮膚では分らない のであろら。一般に陳旧性の病单に於て膠原線維の堌列 が認められるのは上述の如く往々女るが，その際概してて 膠原線維の増殖がそれ性ど著しくないものでは弾力線維 の再生は見られないが，謬原線維の増殖が比較的著明な ととろでは弾力線維の再生が軽度ではあるが見られる。 とのととから弾力線維の再生は閦原線維の再生增殖より も遲れ且つ弱いものであるととが云える。一方に於て瀨 腫性の浸潤が始まり拡がつてりく時には，弾力線維は格 子状線維，翏原線維よりも抵抗が弱く速に变化を受け る。頻腫性の浸潤による弾力線維の断裂, 消失は個々の 浸潤の程度とは必ずしも並行せず，浸潤比較的軽度なる にも拘らず断裂，消失のか店り著明な場合がもる。

格子状線維の態度に就ては之を緾女て後心稿を改めて 述べたいと思ら。

(8) 間質内血管飞就て

間質内血管に余り変化のなかつたものは瀨腫瀨19例中 4例に過ざない。との 4 例もまたもつといろいろな部位
の切片を調べると更に明な変化が認められるかもしれな い。それらの変化のらち最多いのは動脈内膜の肥厚で めり，時には更に中膜も肥厚しているものがもる。内膜 肥厚の為管膹のかなり狭小となつているものがあり，又 No. 14 に於ては小葉間動脈にして内膜肥厚し，管腕内に 索状の瘾着が認められたものが女つた。なお No. 15 及 び No. 16 に於ては動脈中膜が稍々硝子様無構造のもの となつていたものが女つたが，アミロイド变性は認めら れなかつた。時に静脈の内膜の肥厚しているものが認め られた。又 No. 5 に於て間質内血管の管腔内にむる大単 核細胞にしてその中に抗酸性菌がかなり認められ，且小 空胞が形成せられているものがせり，又との血管の内皮 細胞にもかなりの抗酸性菌が認められたものが女つた。 又 No. 3 に於ては間質内の動脈の分岐部の恰も川の中洲 の先端に相当するとてろに著明な瀨腫が形成されている のを吠めた。

（9）胆管に就て

瀨腫瀨费者19例の小葉間の胆管に就てみるに，変化な きもの 7 例, 少数の胆管に軽度の変化を認むるもの 8 例 そのらち一部の胆管壁の線維性肥厚を認むるのみのるの 2 例, 之に上皮細胞の排列不整, 或は上皮細胞の萎縮, 脱落等の認女られる胆管が同時に少数認められるもの 2 例, 上皮細胞の脱落せるものがある胆管の認められるの 又のものが4例。全般に比較的变化の著明なもの4例, 例えば No.11 では胆管増殖し, その周の結締織が増殖 し䏣管の殆どが変化を呈し，殊に小なるものより大なる あのに於て著明で，上皮細胞の脱落が著明で甚だしいも のでは上皮細胞の殆どが脱落し, 内腔にはそれら脱落細 胞と共にへマトキシリンに紫染し殊に極小体の強染せる 桿菌が無数に集合し細線維状の集塊を形成している。そ の他の例でも上皮細胞の脱落, 萎縮, 或は空胞変性や腫 腿, 排列不整, 重層等がみられ, No.20では胆管壁に少 数の小円形細胞の浸澖が認められるものがむつた。しか し之等の例に就てみるに例えば上記の変化の著明でもつ た No.11 では胆垔内に大豆大から梅実大の胆石が20近 くまり, Ductus hejaticus 更に肝蔵内の比較的大きな胆 管中にも多数の石を認め, 所により胆管内に種 々の形 態, 色, 大さの石が連続して並んでいる所があり, 上記 の小葉間胆管の変化は之に起因するものと考えられる。 又一般に胆管にその変化の著明な場合にも, その変化の わりに浸潤は余り認められず，以下の胆道及消化管に瀨 性の変化は余りとないものであり，とれらのととからし て胆管の上皮細胞の脱落, 萎縮, 排列不整等の変化は瀨 
でない因子によつて起されるものであると考えられる。 しかし頙と胆道が全く無縁のものであるというととも断 定できない。No. 20 に於て胆管壁に小円形細胞の軽度の 浸潤の認められるものがむり, 又 No.7 に於て小葉管胆 管上皮及胆管腔内に夫々 1 個の抗酸性菌が認められ，又 No. 9 に於ても小葉間胆管上皮内に抗酸性菌 1 が認めら

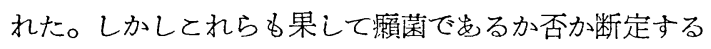
ととはできない。両例はいづれる結核の合併なき例でむ り，結核菌ではないと考えられるが，とれらの菌が単な る非病原性の抗酸性菌でないといらととは断言する根拠 がない。との問題は今後の検討に待つより外はないがい、 づれにせよ瀨と胆管とは関係があるとしてもその関係は 稀でしかも稀薄なものである。胆石に就ては上記の No. 11 の外に No. 7 に於ても胆襄内に 1 個見出された。

\section{(10) 被膜飞就て}

衤腫瀨19例中被膜に瀨性浸潤を認め得なかつたもの 1 例, 軽度に認められたもの12例, 稍々著明なもの 6 例。 被膜の瀨腫性浸潤と実質及間質内の賴腫との関係を見る と表 3 の如くでむり，大体に於て両者の間に比例的な関 係がみられるのでまつて, 被膜に於ける瀨腫性浸潤の発 生に特異な点はない。

\begin{tabular}{|c|c|c|c|}
\hline \begin{tabular}{|r|} 
被膜の瀨腫| \\
実質及間質の癩腫
\end{tabular} & - & + & $H$ \\
\hline+ & 1 & 3 & 0 \\
\hline$H$ & 0 & 2 & 0 \\
\hline H & 0 & 12 & 6 \\
\hline
\end{tabular}

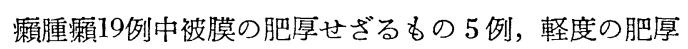
11例, 稍々著明な肥厚を認むるもの 3 例。ただ勿論被膜 の肥厚に就ては顆以外の因子も考えに入れなければなら ない。稍々著明な肥厚を認むるるの 3 例のうち 1 例は, 著明な結核性腹膜炎がめり，被膜にも結核性病单が著明 に認められたものであり, 瀬腫性浸潤は寧万軽度で, 被 膜の肥厚にはとれらのととが関係していると思われる。 そこでとの 1 例は.以下の表より除外し稍々著明な肥厚 2 例とする。今被膜の肥厚と間質堌殖との関係をみると表 4. の如くである。

これよりみると両者の間に稍々比例的な関係が見られ る。乙れは上述の如く被膜に於ける瀨腫性浸潤の程度が 略々実質及間質内の嶰腫と比例するととからみて, 結締 織の項に於て記した如き実質及間質内の瀨腫の陳旧度或

\begin{tabular}{|c|c|c|c|} 
表 & \multicolumn{2}{c}{4} \\
\hline $\begin{array}{c}\text { 被膜の肥厚 } \\
\text { 間質堌殖 }\end{array}$ & - & \pm & + \\
\hline- & 1 & 1 & 0 \\
\hline \pm & 2 & 6 & 0 \\
\hline+ & 2 & 4 & 2 \\
\hline
\end{tabular}

は結締織性反応の差といらものが，被膜に於ても同様に 現れるためであろらと考えられる。な打 No. 8 の神経瀨 例に於て被膜の部分的の軽度の肥厚及び被膜内血管周囲 の小円形細胞, 線維芽細胞, 単球等の軽度の浸潤を認め たが，本例は結核性腹膜炎があり，肝にも結核結節の認 められたものであり, 上記の変化も結核によるものと考 えられる。

(11) その他

顆粒肝の問題に就ては, 典型的な顆粒肝は 1 例も認め られずただ 6 例に於て部分的に軽度の顆粒状の凹凹が 認められたに過ぎないるその多くは顆粒の大さは小葉大 でめり，偽小葉の形成を示咬するものは余りなかつた。 ただとの際それらの例のらち 3 例に於て肝の横隔膜面よ りも寧ろ内臟面に於て叫凸が認められる傾向がもり, 又 他の 2 例はいづれも勿論小部分の凹凹であるが肝緣に近 い部分に認められた。な打 No.16 に於て東洋絞索溝が 認められた。

\section{結 論}

瀨患者剖検例20例（瀨腫瀨19例，神経瀨 1 例）の肝淢 の肉眼的及顕凯鏡的所見を調へ，併せて皮㾸との関聯を も考察して次のととを知つた。

（1）瀨腫䅡患者に於て，主に皮膚の瀨腫の程度より決 定する病度と肝の瀨腫の程度とは大体に於て比例する。

(2) 同じ病度のものでは皮疹の吸収度が高いものは， 低いものに比べ肝の癩腫性病巣の数が稍少い。

（3）皮疹の吸収度と，肝の瀨腫の組織所見及び細菌所 見に於ける軽快度は大体に於て比例する。一旦軽快後増 悪の場合にも皮疹の経過と肝の顀腫の経過は比例する。 しかし決して肝の病変が皮啗の病変に従属するものでは なく, 時には肝に於ける局所的な病巣の増覀が起り, そ れが皮痛を始め全身的な堌悪の源となる場合もむると考 えられる。

（4）小葉内と間質内に於て，そとの病巣の進展経過が 稍々異る場合がむる。 
（5）肉眼的にみて黄色の色調の強い楉腫と，白色の色 調の強い、顀腫とが告るが，かかる差はその瀨腫内の顀細 胞のリポイド球の大さと密度によるるのでせる。

(6) 应行性に撒布された菌の肝に於ける附着は常に均 等とは限らず，肝葉により又一葉の中でも部位により異 る場合がある。

（7）病巣が新しいらちはその中の菌は桿状のものが多 いが，陳旧性のものになるに従、その中の菌は顆粒状等 の変型菌が多くなる。この点に関して星芒状細胞内の菌 も経過を異にするものではない。

（8）肝細胞は勿論瀬以外の多くの因子の影響もらける が，肝細胞の萎縮，溒死，消失に関しては小葉内に無数 の欋腫が生じたためその圧迫によるるの或は瀨性病変に よる中心静脈の狭窄或は閉鎖の為の局所的な爵血による もの等直接間接に顆に起因するものがある。

（9）㸊による肝細胞の脂肪変性は周辺脂肪化の形をと るものが多い。

(10)瀨と結核に於て中心静脈の侵し方に稍々差が女 り，瀨の方が結核よりも著明に侵す傾向がもる。

(11) 間質増列は肝の濑性病変の程度に略々比例する が，その他に癩腫瀨に於ては病巣のうち陳旧性の吸収期 の櫴腫の占める比率に影響され，又一般に個体により結 䋨織性反応の強さに差があると考えられる。

(12) 癩腫性病栄に於て, 弾力線維は格子状線維及び膠 原線維よりも抵抗力が弱く, 速に且つ著明に断裂, 消失 し再生も幄れる。かかる著明な断裂, 消失と共に一方に 於て僅かではあるが弾力線維の新生を伴らととが時にも る。

(13) 間質内血管殊に動脈は屡々变化を受け，その变化 のらち最も多いのは内膜の肥厚でむる。時に静脈も变化 を受ける。

(14) 小葉間胆管が瀨と関係がないとは断定し得なかつ たが，例令むつたとしても稀に稀薄な関係がもるに過ぎ ないと考えられる。

(15) 被膜に於ける瀬腫性浸潤の発生は，実質及び間質 内のそれと大体に於て比例する。被膜の肥厚に就ても， 間質の増殖に於けると同様にやはり個体による結綂織性 反応の強さの差といらものが関与する。
(16) 典型的な顆粒肝は 1 例もなかつた。

本研究に対し御指導を頂いた林, 阿部, 義汇, 田尻, 立川の諸先生に感謝の意を表し, 併せて本稿の御校閲の 労をとつて頂いた北村, 林の両先生に深芫なる感謝の意 を表します。

\section{主要なる文献}

1）小林和三郎：内㖪瀨に就て，皮唐科紀要モノグラ ᄀ, 皮唐科学研究叢書第 4 輯（昭和 3 )

2）宗内敬男：癩の病理（五，：治療及処方， 15,122 (昭和13)；癩屍に於ける肝臟の病理学的知見禣遗 皮耖誌, 43,226 (昭和13)

3）藤田敬吉: 全生病院に於ける病理解剖例の概葓.レ プラ, 9,113(昭和13)

4) 林 芳信: 隺屍剖桧 1200 例に就ての綜合的観察. レプラ, 10,27 (昭和14)

5）阔田誠太郎：ビオプシーによる人瀬及び鼠 瀨の肝 微病变の病理組"織学的研究 (第 $1 \sim 5$ 報). レプ ラ, 22,298 (昭和28)；同 23,1 (昭和29); 同 23,8 (昭和29)

6) Schäffer : Die visceralerkrankungen d. Leprösen Die Lepra, 1, 11 (1900) ; 2, 57 (1902)

7) Neisser: Histolog. u. Bacteriolog. Leprauntersuchungen. Virchow's Archiv, 103, 355 (1886)

8) Doutrelepont u. Wolters: Beiträge zur Visceralen Lepra. Archiv f. D. u. S. 34, 55 (1896)

9) Musehold: Lepra d. Leber u. Milz. Verhandl. d. Internat. Lepra Konferenz, 3, 413 (1897)

10）菅井竹吉：内㶓瀨につきて. 皮必誌，11，1 (明治 44)

11）竹崎季薰：㗍病の脾肝につきて. 東京医事新誌, 1355, 7 (明治37)

12）光田健輔: 内臓瀨に就て. 「光田健輔, 瀨に関する 論文」第II 輯, 12 (1950)

13) Klingmüller: Die Lepra. Lehrbuch d. Haut u. Geschlechtskhten, 10, 379 (1930)

14）稻葉俊雄：㸊屍に於ける顆粒肝に就て.レプラ, 8, 176 (昭和12) 